\title{
HETEROCHRONY AND MORPHOLOGIC DIVERSITY OF ORDOVICIAN ISOTELINE TRILOBITES.
}

\author{
MILLS*, Brenda, Dept. of Earth Sciences, Brock University, St. Catharines, Ontario \\ L2S 3A1; WESTROP, Stephen R., Dept. of Earth Sciences, Brock University, St. \\ Catharines, Ontario L2S 3A1
}

In recent years, ontogenetic studies of isoteline trilobites have focused on the use of protaspid morphology in high level classification. However, new biometrical data on the meraspis and holaspis stages of silicified Middle and Upper Ordovician species of Isotelus and Anataphrus from the Mackenzie Mountains, northern Canada, indicate that allometric changes in several dimensions characterize the later ontogenetic development of isotelines. Late meraspid to holaspid development of Isotelus involves substantial modification of both pygidial and cranidial outline. Transitory pygidia are relatively broad and well-rounded posteriorly but holaspids are more elongate and subtriangular in outline. Holaspid cranidia are also more triangular in outline and palpebral lobes become both relatively smaller and increasingly elevated above the level of the fixed cheeks. Heterochronic shifts along this developmental path account for interspecific differences between species of Isotelus. The ontogenetic trends are accentuated further in the genus Ectenaspis, which has a sharply triangular cranidium with a long, anterior "snout" and strongly elevated palpebral lobes By contrast, Anataphrus follows an alternative developmental path in which the juvenile, posteriorly rounded pygidial morphology is retained into the holaspis stage; both the cranidium and pygidium become strongly effaced. Nahannia also retains a posteriorly rounded pygidium but is less effaced than Anataphrus. Holaspid cranidia of some species of Nahannia possess long palpebral lobes. In this respect, they resemble juveniles of the other isoteline genera, which are characterized by a reduction in the size of the palpebral lobes in holaspis stage. Thus, heterochronic shifts along two primary developmental paths appear to be sufficient to account for the range of cranidial and pygidial morphologies present in Middle and Upper Ordovician isoteline genera. 